\title{
Securitization and desecuritization: a dramaturgical analysis of the Canadian Air Transport Security Authority
}

\author{
Mark B. Salter \\ School of Politics, University of Ottawa, Ottawa, Ontario, Canada K1N 6 N5. \\ E-mail: msalter@uottawa.ca
}

Securitization theory has evolved over the past 10-15 years and has fuelled much exciting research, demonstrated through recent contributions by Balzacq, Stritzel, Taurek, and Floyd. Despite a growing number of case studies of successful securitization and desecuritization processes, scholars have retained the statist view of securitization: actors identify an existential threat that requires emergency executive powers, and, if the audience accepts the securitizing move, the issue is depoliticized and is considered a 'security' issue outside the rules of normal politics. This article demonstrates that there are multiple settings of securitizing moves and parses the audience within securitization theory, suggesting a model of at least four distinct types of audiences and speech contexts (popular, elite, technocratic, and scientific). The process of securitization is not a moment of binary decision but rather an iterative, political process between speaker and audience. We must not ask, 'was a securitizing move made' but 'how does a securitizing move mean?' Particularly if one adopts a more interventionist or activist notion of scholarship, a key question for experts must be: how are securitizing moves accepted or rejected? What are the politics of that successful process of (de)securitization? Using dramaturgical analysis, we suggest that securitizing moves take place within different sociological settings that operate with unique rules, norms, and practices. The example of the Canadian Air Transport Security Association is provided. Journal of International Relations and Development (2008) 11, 321-349. doi:10.1057/jird.2008.20

Keywords: aviation security; Copenhagen School; dramaturgy; securitization

\section{Introduction}

This article will lay out the original logic of the Copenhagen School (CS) regarding the processes of securitization and desecuritization. The recent supplements to this theory by Balzacq and Stritzel will then be summarized. This literature review demonstrates that there is common reduction of the speech act-audience relationship in securitization theory that must be theorized further. Dramaturgical analysis adds to this model a more nuanced understanding 
of audience-speaker co-constitution of authority and knowledge, the weight of social context, and the degree of success of (de)securitization. This dramaturgical analysis, then, does not abstract the speech act from its sociopolitical or organizational context, but rather situates the securitizing move in a particular local 'regime of truth', in a particular setting and in time (Foucault 1980). Four different settings explain variations in the form, content, and success of speech acts: the popular, the elite, the technocratic, and the scientific. In each of these different settings, the core rules for authority/knowledge (who can speak), the social context (what can be spoken), and the degree of success (what is heard) vary. This goes far beyond linguistic rules towards norms and conventions of discourse, as well as bureaucratic politics, group identity, collective memory, and self-defined interest. The second half of the article plots these concepts and relationships within a 2-year period when the Canadian Air Transport Security Authority (CATSA), responsible for key elements of Canada's aviation security system, underwent a series of formal reviews.

Though guided by Jackson and Nexon's (1999) admonition for a processual/ relational international relations method, this paper differs from other critiques of securitization theory. Rather than engage on an internal critique of the specifics of speech-act theory, from which the CS drew the theoretical base of securitization theory, this article examines the political nature of (de)securitizing moves. Interviews with security experts, government officials, and other scholars conducted by the author demonstrated radically different understandings of the exact same processes of securitization: experts were eager to 'cash in' on newly available security budgets, government bureaucracies were concerned with the measurement of security, while scholars attempted to desecuritize the issues of risk management and profiling. As such, it was clear that there was not a single securitizing move that was accepted or rejected, but a much more complex play of competing authorities, power metrics, and discourses. Different security games were played out within the same sector, each had different rules, different actors empowered to speak, and different standards of proof existed. We found that on separating these different debates into settings - borrowed from Goffman's dramaturgical analysis - we could better identify key debates, actors, and factors of success for particular securitizing moves.

This model of settings for securitizing moves fits cleanly with Paris School interventions on the trope of risk (Aradau and van Munster 2007; Aradau et al. 2008). However, it is precisely because security plays differently to each audience, is used differently by different speakers, and changes in its meaning that we need to expand our analysis of how securitizing moves are accepted or rejected. Bigo (2006: 7) uses the notion of 'field' to demonstrate how 'these professions do not share the same logics of experience or practice and do not converge neatly into a single function under the rubric of security. Rather, they 
are both heterogeneous and in competition with each other'. This article offers a way into that field analysis of securitization, that is not reduced to linguistic analysis, through a dramaturgical analysis of setting: within each securitizing move, we must consider who may speak, what may be spoken, and what is heard.

\section{Securitization}

Securitization theory has been an incredibly fruitful approach for the study of security. Having disaggregated 'state security' into several sectors (military, political, societal, economic, and ecological), Buzan argues that 'the question of when a threat becomes a national security issue depends not just on what type of threat it is, and how much the recipient state perceives it, but also on the intensity with which the threat operates' (1991: 133-4). This was expanded by Buzan, Waever, and de Wilde in the formal model of securitization: 'the intersubjective establishment of an existential threat to have substantial political effects...to break free of procedures or rules he or she would otherwise be bound by...' (1998: 25). The attempt at securitization is called a 'securitizing move', which must be 'accepted' or rejected by the target audience. The authors argue that the conditions for success are (1) the internal grammatical form of the act, (2) 'the social conditions regarding the position of authority for the securitizing actor - that is, the relationship between the speaker and the audience and thereby the likelihood of the audience accepting the claims made in a securitizing attempt, and (3) features of the alleged threats that either facilitate or impede securitization' (1998: 33). There is room within the original cast of the theory to expand the notion of facilitating conditions or impediments for securitizing moves - but little direction as to what those might be. In this reading, the second factor - these social conditions - is under-determined and must be explored further.

In the debate between the CS, so named in a response by McSweeney (1996, 1998), subsequent replies (Buzan and Waever, 1997), and a provocative intervention by Williams (2003), a number of critiques of the model of securitization were raised. The CS was faulted by McSweeney for appearing to give an ontological pre-existence to the 'speaker' and 'audience' that is at odds with a more processual or constructivist perspective of identity (1996: 83). Williams argued that different kinds of speech might constitute an act, and made an important theoretical connection to Schmittian politics of sovereign exceptionality. Williams wrote that the CS process of securitization - notably that securitization implies depoliticization - can be found in other theories of sovereign authority, and that securitizing moves are an attempt by the sovereign to decide the exception and thus remove the sector from democratic 
debate (2003). Buzan, presented a spectrum of how issues might be weighted: 'nonpoliticized ... through politicized... or securitized' (1998: 23). Within this account, the CS appears to represent securitization as a threshold particularly within a democratic society. Either a threat is represented and then accepted as a security issue, or it remains contested within the realm of normal, deliberative politics.

Successful securitization is at root a political process, but the actual politics of the acceptance are left radically under-determined by this model. The authors argue that 'the issue is securitized only if and when the audience accepts it as such... (it must) gain enough resonance for a platform to be made from which it is possible to legitimize emergency measures...' (1998: 25). It is precisely the dynamics of this acceptance, this resonance, this politics of consent that must be unpacked further. The Copenhagen School, certainly open their model to consideration of the 'external, contextual, and social roles and authorized speakers' of the speech act 'and, not least, under what conditions (i.e. is the securitization successful)' (1998: 32). But, within their model, there is no frame for how securitizations are successful or fail.

A subsidiary point that is worth noting: these external and internal conditions for securitization appear to work in reverse for the process of desecuritization (Wæver 1995). The speaker proposes that there is not a threat, or at least not a threat that is existential, and that the problem can be comprehended or managed within the rubric of normal politics. There are a number of assumptions within articles about securitization theory about the differential ease or difficulty of securitization and desecuritization. These unexplored assumptions arise because there is no theory for the actual process of the success or failure for a securitizing or desecuritizing move.

The statist model of securitization does not match the complexity of contemporary social dynamics of security. First, other non-state actors must be included in the model, as demonstrated by Bigo (2006) and others. Security is not contained solely within the traditional boundaries of the state and the authority to make securitizing moves not limited to state actors. Second, two temporal dimensions must be added to considerations of securitization and desecuritization: the duration of the securitization and the entropy of the public imagination. Some issues, such as the war on drugs, rose and faded in the public imagination, largely independent from the 'actual' or empirical degree of threat (Campbell 1993; Aradau 2001). Third, securitization is not an instantaneous or irrevocable act. Rather securitization reflects the complex constitution of social and political communities and may be successful and unsuccessful to different degrees in different settings within the same issue area and across issues. Floyd demonstrates convincingly that desecuritization is entirely 'issue-dependent rather than static' (2007: 349). Nor is securitization an 
act that removes an issue from deliberative politics forever. Rather, studies of securitization need to account for the movement of issues into and out of the security sector over time. An issue that has faded from the public view may rest within the security frame or enjoy a kind of 'entropy' where the public, elite, technocratic, or scientific communities assume that exceptional security measures have lapsed in the face of a threat that no longer seems pressing or relevant. Hysteria over the presence of communists and homosexuals within government departments no longer seems a national security threat, in the way that McCarthy and others described.

For example, a securitization act may be successful with a scientific or technocratic community, and yet fail in the elite and popular realm, such as the debate over global warming during the 1980s and 1990s. A process of desecuritization may occur within popular politics, while elites and professionals remain unconvinced, such as transportation safety. Doty examines how the Minutemen along the US-Mexico border consider themselves to be acting in a 'decisionist' mode, even though they are not sovereign actors (2007: 129-31). A particular group has successfully securitized illegal migration at the border for a segment of the population, while simultaneously human rights groups - by placing water in the desert and advocating for amnesty - act as if the issue is politicized. John McCain (Arizona Senator and Republican Presidential nominee) proposed legislation (with Democratic Senator Edward Kennedy, for whom 'all politics are local') that would provide a 'path to citizenship' and border security - only to withdraw it in the face of public criticism. In this case, the issue was the subject of intense 'normal' political debate, and the securitizing move was incomplete and heterogeneous across the political landscape.

The model provided by the CS gives us no way to measure the success or failure of a securitizing move. In this article, I gauge the success or failure of a securitizing move by ranking the degree to which policies, legislation, and opinion accords with the prescriptions of the speech act:

(1) To what degree is the issue-area discussed as part of a wider political debate?

(2) Is the description of the threat as existential accepted or rejected?

(3) Is the solution accepted or rejected?

(4) Are new or emergency powers accorded to the securitizing agent?

Debated-existential threat-solution accepted-emergency powers

Failed securitizing move

Securitization

This scale of success-failure is particularly useful in assessing the persistence of a security issue within different audiences. A more nuanced notion of success and failure also gives us a purchase on whether an issue remains securitized 
over time so that we may develop a theory of the public imagination in the future.

Two recent contributions to securitization theory stand out for my analysis. ${ }^{1}$ Balzacq and Stritzel share my excitement about the potential of the CS, and my worry about the under-developed social aspect of securitization. Stritzel leads the theoretical debate, and provides a strong grounding for this present article. He argues 'too much weight is put on the semantic side of the speech act articulation at the expense of its social and linguistic relatedness and sequentiality' (2007: 358). He critiques the under-theorization of the speakeraudience relations, stating that 'in empirical studies one cannot always figure out clearly which audience is when and why most relevant, what implications it has if there are several audiences, and when exactly an audience is "persuaded" (2007: 363). Stritzel proposes an embedded analysis of securitization: '(1) the performative force of the articulated threat texts, (2) their embeddedness in existing discourses, and (3) the positional power of actors who influence the process of defining meaning' (2007: 370). By this, he argues, the discourse of securitization must be understood as situated within a relationship between speaker-audience and within a context that predates the actual securitizing act. What makes a securitizing move successful is, for Stritzel, the extent to which the actor has the power to make the threat and the discursive weight of that threat (has it been well established, or is this a new threat?). Stritzel's general model of embedded securitization is productive, but does not explain the success or failure of securitizing moves with any greater clarity than the CS. It is a useful framework that can guide empirical work, but it does not allow us to generate any hypotheses about the politics of securitization and, in particular, about securitizing moves that fail to garner acceptance or resonance. Adding the range of success/failure, as detailed above, helps Stritzel's embedded analysis disaggregate 'persuasion' into multiple steps of audience acceptance.

Balzacq also offers a model of the social aspect of securitization that includes 'the context, the psycho-cultural disposition of the audience, and the power that both the speaker and the listener bring to the interaction' (2005: 172). In posing the question of strategic or pragmatic practice, Balzacq argues that 'the positive outcome of securitization, whether it be strong or weak, lies with the securitizing actor's choice of determining appropriate times within which the recognition, including the integration of "imprinting" object — a threat — by the masses is facilitated' (2005: 182). His examples demonstrate that these choices are constrained by history, memory, and discursive tropes. What a dramaturgical analysis adds is the notion that - just as there are different national and psycho-cultural contexts - so too are there different sociological, political, bureaucratic, and organizational contexts within a populace. A popular audience will 'accept' securitization of threats differently to an elite or scientific audience. Global warming as an environmental securitization, for 
example, has had creeping success - but on radically different grounds with scientists, bureaucrats, elite politicians, and the populace (both within states and between states). It is unclear to me if 'securitizing agents always strive to convince as broad an audience as possible' (2005: 185), particularly within the context of security professionals (Balzacq 2008). In the case study below, the securitization of Canadian civil aviation security was pitched to narrow, specific audiences - and there was little effort to securitize the issues for the general public. At a base level, popular politics (at least in democratic societies) operates differently than scientific politics; technocratic politics from elite politics. In short, in addition to the 'régime of truth, [a society's] "general politics" of truth' (Foucault 1980: 131), there are also specific politics of truth. Foucault hints at these specific regimes of truth in discussing the relationship between the specific intellectual and 'direct and localised relation[s] to scientific knowledge and institutions' (1980: 128). I return to these notions of direct and localized relations in the case study. This is why a dramaturgical approach to the actual evolution of particular securitizing moves is so productive; the language and political games at stake in each setting are radically different.

Balzacq has gone on to argue that 'securitization sometimes occurs and produces social and political consequences without the explicit assent of an audience' (2008: 76). He uses the new governance literature to propose a new investigation into policy tools that are 'instruments of securitization' (2008: 79). Both Balzacq's work and this article are attempting to remedy the same flaw in the CS's methodology: an overreliance on speech acts to the neglect of the social. A dramaturgical analysis of setting, however, provides the audience that Balzacq displaces. It is crucial to our analysis that the audience is determinative of the form of securitizing move. Even if those audiences are internal or organizational, as Goffman explains: 'no audience, no performance' (1974: 125). He argues,

if one individual attempts to direct the activity of others by means of example, enlightenment, persuasion, exchange, manipulation, authority, threat, punishment, or coercion, it will be necessary, regardless his power position, to convey effectively what he wants done, what he is prepared to do to get it done and what he will do if it is not done. Power of any kind must be clothed in effective means of displaying it, and will have different effects depending upon how it is dramatized. (1959: 241, emphasis added)

Viewing securitizing moves as a kind of performance, we can see the importance of 'front' and 'backstage': that the same securitizing speech acts may be framed differently within the professional team and in front of an audience. Among themselves, (security) agents may speak in one way, but use other ways to conform to the expectations of a popular audience - and there are some that are always totally excluded from the securitizing process 
(1959: 145). The audience is not always the public. There is a network of bureaucrats, consultants, parliamentarians, or officials that must be convinced that securitization is appropriate, efficient, useful, or effective. Balzacq identifies a series of backstage securitizing moves that have public effects, though are never securitized publicly. Rather than disappear the audience, a more flexible notion of the setting of securitization allows for micro-sociologies of the particular securitizing moves.

\section{Dramaturgical Analysis}

Dramaturgical analysis uses the vocabulary of the theatre to understand social settings, roles, and performances of identity. Sociologist Goffman also introduced the notion of the 'framing' of identities and issues, to which much critical scholarship is indebted (1974). ${ }^{2}$ Much post-structuralist work relies on notions of performance, and critical work in international relations often assumes that key political divisions such as inside/outside, order/anarchy, self/ other must be continually performed and reinforced to have effect. In this research programme, I am interested less in the national application of Butler's notion of the performativity of gendered and other identities (1990), Campbell's (1993) notion of foreign policy as an articulation of danger that acts as an identity function, Sylvester's analysis of 'dramaturgies of violence' (2003a) or 'development' (2003b), important and provocative though they may be. Instead, this dramaturgical theory argues that the setting of a securitizing move is determined by the actors and their roles, the rules of the discourse permissible within that space, and the expectations of the audience. When we push this theatrical metaphor, we can classify the different types of securitizing moves that all share similar conventions, narratives, characters, and tropes. The use of specialized language, procedural forms, and common conventions all suggest a common setting. ${ }^{3}$ For example, terms, precedents, or issues whose specialized meanings both speaker and audience share. ${ }^{4}$

Buzan et al. themselves use dramatic language: 'the staging of existential issues in politics to lift them above politics... an issue is dramatized and presented as an issue of supreme priority...' (1998: 26). Huysmans alludes to the 'security drama' and leads to this focus on 'the processes of security' (1995: 66). Rather than classify securitizing moves as comedies, tragedies, and histories, we can classify them according to the setting: popular, elite, technocratic, and scientific settings. Each of these settings structures the speaker-audience relationship of knowledge and authority, the weight of social context, and the success of the securitizing move. The setting of a securitizing act includes the stage on which it is made, the genre in which it is made, the audience to which it is pitched, and the reception of the audience. 
What is particularly useful about Goffman's dramaturgical analysis is precisely the mutual constitution of self and audience. The characters in the drama must use information to convince the audience of a particular story: 'the over-communication of some facts and the under-communication of others... a basic problem for many performances, then, is that of information control' (1959: 141). The setting of a performance, then, communicates the groundrules for who may speak, what may be said, and what is heard. For example, when Shakespeare was originally staged, groundlings, who paid little admission and sat in the stalls below the stage, might speak to and throw food at the actors - something probably frowned upon at Stratford-uponAvon today. British pantomime has a particularly interactive audience-actor relationship (oh no it doesn't, oh yes it does), as does the Rocky Horror Picture Show, both of which rely on the audience knowing the call-and-answer structure of the drama. This is to say that in addition to an awareness of the language, tropes, metaphor, plots, and devices that are embedded in the process of securitization, dramaturgical analysis also directs our attention to the constitution of the actor-audience in a particular discursive relationship. Also, Goffman argues that the presentation of the self changes from different social settings, and that an understanding of the setting can illuminate the exigencies of different performances. For him, the character and audience join together in a 'working consensus' to create 'the belief that ([he performer] is related to [the audience] in a more ideal way than is always the case' (1959: 48). Any social scene, such as the setting of securitizing moves, involves the presentation of a self, the setting for that narrative, and audience reception. Speech-act models of securitizing miss the crucial aspect of the 'setting' of the narrative. In particular, the setting of a political speech act includes the stage upon which the securitization is attempted (national, organizational, bureaucratic, or scientific) and also the past narrative history of failed and successful securitizations by lauded or derided characters (Merelman 1969: 225). ${ }^{5}$

Securitizing moves in popular, elite, technocratic, and scientific settings are markedly different - they operate according to different constitutions of actor and audience. A securitizing move is not the same in all contexts, because it is not simply made up of the internal grammatical elements. Krebs and Jackson analyse the importance of public rhetoric, while bracketing the questions of motivation (2007: 41). Whether the intention of the speaker is entirely calculative or emotive, the rules of the setting remain the same (Goffman 1959: 66). A securitizing move made for political gain or from fear adheres to the same logic, but the effect of the message may be different. This focus on the reflexive relationship between speaker and audience is particularly important for theories of securitization. Securitizing moves follow an internal grammar that is determined not simply by internal rules (i.e. the invocation of an emergency or exception to normal politics), but also to a common, social 
grammar (i.e. the universe of tropes, images, metaphors, histories that can be invoked). Securitizing moves occur within the universe of the audience imagination. It is not simply a power relationship — but a knowledgeauthority game.

A popular securitizing move may be prompted by an informal authority such as a civil society group (like the Minutemen along the US-Mexico border); but, civil society groups may be ineffective in scientific settings (Minutemen and similar groups do not participate in academic or professional arguments about border security). A scientist will use different authority to convince her colleagues than her bureaucratic counterparts. For example, the case for the presence of weapons of mass destruction in the lead-up to the most recent American invasion of Iraq illustrates how ambiguity was leeched from the technocratic discourse as it was marshalled in the popular sphere. Uncertainty was purged as the reports were summarized, as technocrats aimed to convince the political elite, and in turn as the elite aimed to convince the general populace. In short, the 'acceptance' of the audience and the 'resonance' of an existential threat is different within different spheres. I argue that we can distinguish these distinct settings by the grand narratives by which truth is authorized, the characters who are empowered to speak, and the relationships between characters and audience. Within the security sphere, different narratives are deployed for security threats in different sectors; different characters may attempt a securitizing speech act; and the relationship between the audience and the performer structure how those speech acts are made and received.

This model of different settings for securitization stems from research into the widening of public security in post-9/11 politics. There is a consensus among critical scholars that the amount of social life that is governed by 'security' claims has increased since $9 / 11$ - but not all securitizing moves have been successful. In studying the evolution of civil aviation security, it was clear that the rules of the speech act were different in different settings: who could speak, who could hear, and what could be said all varied radically - even on the same issue within the same sector. Using the case of the CATSA below, I argue that there are four key settings for these securitizing moves. This is not to say that, in other contexts, more settings are not possible, but rather that the four settings are the fewest number of categories that allow for significant differentiation within this case.

The changing nature of perceptions of the aviation sector over the past 40 years demonstrates the importance of time and entropy within securitization studies. The gradual and increasing securitization of international aviation has been a long process, one in which terrorist groups rather than government elites have been the organizational and discursive entrepreneurs. The travelling public has a short memory, politicians aim at the next election cycle, and 
bureaucrats are risk averse. Securitization has occurred at once or necessarily as a result of one speech act that is accepted or rejected but often through the imposition of new regulations or international standards. The setting of securitization is clearly crucial.

The success of a securitization act is dependent not exclusively on the formal syntax or on the informal social context, but also on the particular history, dominant narrative, constitutive characters, and the structure of the setting itself. A popular appeal to national security is often effective in popular and elite politics, but may be less convincing in a scientific realm. The restrictions of mandate and bureaucratic thinking will predominate in technocratic politics in (at least potentially) different ways to the decision making of elites bent on maintaining power or gaining reelection. The setting also determines the characters that may attempt a securitizing speech act. Imams and ministers have an authority to name cultural and moral threats to society within the setting of popular politics, but there is a different stage presence about scientific truths. For example, American librarians had a surprise entry onto the popular scene due to their perceived scientific interest in privacy and free speech, which trumped elite policy demands in the realm of popular politics during the debate surrounding the total information awareness proposal (Abdolian and Takooshian 2003; Monahan 2006). The disproportionate effect of librarians in this public debate cannot be explained simply by power differentials as in Stritzel or Balzacq. Different actors possess different authorizations to speak in different political settings.

In the following case, the same securitizing move (to expand aviation security and airport passenger security) was made by different actors, to different audiences, with different claims to authority, in different languages, with different effects. This was evident over time as the securitizing move was accepted or rejected by the target audience.

\section{Securitization and CATSA}

CATSA provides an excellent case for dramaturgical analysis. ${ }^{6}$ There is a clear and accepted securitizing move in response to the attacks of 9/11: the creation of CATSA. Because the 9/11 attacks were directly connected to failures in airport security, specifically passenger screening, the securitization of civil aviation was relatively straightforward: the external threat of terrorists using planes as weapons of mass destruction had a deep resonance across the populace, political elite, technocrat, and scientific audiences. ${ }^{7}$ In particular, the real-time broadcast of the second plane hitting the World Trade center, and the repetition of those images, gave aviation security a dominant position in the public imagination of homeland security. Previous to $9 / 11$, in Canada 
(and the United States) aviation passenger screening was done by airlines according to national standards set by the transportation authority. Airport security was not a realm of emergency or crisis, and could be handled by non-state entities (like airlines or airport authorities). It was depoliticized, expressed in terms of cost and regulations and technical standards. To nationalize airport security - make it part of the governmental structure, through CATSA - represented an expansion of governmental powers that was due to a perceived emergency and existential threat. ${ }^{8}$ The securitizing move was successful, even easy. However, this does not tell us enough about the process of securitization.

During 2004-2007, there were several other securitizing and desecuritizing moves. There are clear popular, elite, technocratic, and scientific communities that engaged in these (de)securitization processes. Popular sentiment can be evaluated through public media, particularly in 2006. Furthermore, in 2004, CATSA engaged the scientific community in an examination of its security strategy, the proceedings of which were then published in 2006. Elite, technocratic, and scientific settings are evidenced through a 5-year governmental review of the CATSA Act in 2005-2007 and an Auditor-General Special Examination of CATSA in 2006. In these reviews, experts, bureaucrats, and policy-makers evaluated the security function of CATSA. In particular, the CATSA Act Review, conducted by Transport Canada with a wide range of public consultations, provides a thick slice of public, scientific, technocratic, and elite opinion after 5 years of operation. During these two critical reviews, the CATSA executive attempted to convince the elite of the need for an expansion of their mandate. In other words, a further securitization of airport security was called for. This was rejected by the technocrats, experts, and the elite. The CATSA case thus provides us with a clear sector that is successfully securitized, popular and expert challenges to that securitization, and a rejection of an expansive securitizing move.

There is thus a prima facie case for a successful securitization move in the area of aviation security in Canada. Before 9/11, passenger screening was done by airports and airlines according to standards set by Transport Canada. Despite Vancouver-based attacks on Air India in 1985, there had been a general trend towards the depoliticization of airport security. It was a subject accessible to public debate, but not politically salient (referenced in political campaigns or in parliamentary debates). Transport Canada was the owner/ operator of the majority of airports, and consequently was responsible for passenger screening. Airport policing, which had been the responsibility of the federal police force (RCMP), was conducted by regional forces. Following the 9/11 attacks, Finance Minister Paul Martin submitted a budget that included the creation of the CATSA. The CATSA Act received royal assent on 27 March, 2002, as a new crown corporation responsible for 'effective, efficient 
and consistent screening of persons accessing aircraft or restricted areas through screening points, the screening of the property in their possession or control, and the screening of the belongings or baggage they give to the air carrier for transport' (CATSA Act Review 2006: 13). ${ }^{9}$ On 31 December 2002, CATSA undertook responsibility for all passenger screening. The creation of CATSA and its initial responsibilities was supported by the Minister of Transport and Finance Minister Paul Martin, who shortly thereafter became the Prime Minister and issued Canada's first National Security Strategy. There was a clear case for securitization: the threat of terrorism particularly to civil aviation was acute, the previous system of privatized or deregulated screening might lead to inconsistencies among Canadian airports which fundamentally threatened the integrity of the system, and, finally, running counter to the trend towards deregulation in civil aviation, the government had a security role. This opinion was exemplified in the National Security Strategy (Canada. Office of the Auditor General 2006: 36).

In the following sections, this article parses the four settings of securitizing moves in the civil aviation security sector during 2004-2007. The traditional CS explanation would go this way: the Canadian state made a securitizing move to define the terror threat to civil aviation as an existential threat that required extraordinary action; this move was accepted by the public, and CATSA was formed in 2001-2002 with new powers and authorities (in evidence through the changes to the Aeronautics Act). The Canadian state has not attempted any significant securitizing moves since the formation of CATSA. However, a close reading of the evolution of CATSA, and, in particular, the reviews in 20052006, demonstrates a much more complex picture of securitizing moves and counter-moves.

Within the elite setting, political and bureaucratic actors actively debated the roles and responsibilities of CATSA and attempted to increase or decrease the powers and authorities of the organization. Within the popular scene, CATSA became the subject of a number of journalistic and public government reports by a Senate committee that questioned the nature of the threat to aviation security and the appropriate policy responses. Within the scientific setting, academics and experts attempted to desecuritize the work of CATSA through a critical appraisal of the risk management approach. Within a technocratic setting, the ability of CATSA to provide and measure security was radically questioned by the Auditor-General, leading to a desecuritizing move. Running throughout all of these settings, there is a common thread: the CATSA executive wanted to increase its mandate, including more counter-terror operations in its operational purview. This particular securitizing move followed the same pattern: existential threat and new powers needed. However, this same securitizing move was made in different ways in different settings. 


\section{Elite}

The CATSA Act Review provides a productive snapshot of the securitizing moves in play between 2005 and 2006. The Minister of Transport, later Transport, Infrastructure and Communities, appointed an expert advisory panel in November 2005 to report on CATSA after 5 years of operation, which was tabled in Parliament on 12 December 2006. ${ }^{10}$ The Advisory Panel had a wide remit to 'examine the provisions and operations of the CATSA Act to ensure that the legislation provides a sound and adequate statutory basis for CATSA's aviation security mandate, provide advice on future aviation security requirements and other developments that may impact on CATSA's future operations... on other important issues that come to [the Panel's] attention' (CATSA Act Review 2006: 15). In the preparation of their report, the panel conducted a number of public consultations and received submissions from over 40 agencies, institutions, airports, organizations, and individuals. CATSA itself also prepared a number of position papers. This is a complex situation for the study of securitization: the three experts on the advisory panel are the primary authors of the report; they are guided and supported by a bureaucracy from Transport Canada; the final audience is the Minister of Transport. Because the audience of this legislative review was the Minister of Transport, Communities and Infrastructure (and other political decision-makers), I analyze this process as part of the elite process. The Auditor-General's Special Examination, though it occurred in a similar timeframe and with consequences for CATSA's Board, was conducted with reference to the Office of the Auditor-General which has a defined mandate. Thus, I examine the Special Examination below as part of the technocratic audience.

It was clear that the mandate of CATSA was in contention. There was a potential within the social space for a securitizing move. The Panel notes: 'it is apparent to the Panel and to many stakeholders that clarification is needed concerning the operation mandate of CATSA and Transport Canada... CATSA thinks it should determine the "hows" [of security functions], while Transport Canada insists they are to be determined within the [Security Screening Order]' (CATSA Act Review 2006: 146). CATSA argued in their submissions that Transport Canada's Security Screening Order was extremely detailed in its prescription, and made security screening inflexible. CATSA made a clear securitizing move: a threat, which was existential, that required extraordinary action - in this case the expansion of its mandate and the transformation of an aviation screening corporation into a counter-terrorism agency (CATSA 2006a: 4). In particular, it was argued before the Advisory Panel that the CATSA Act, Canadian Aviation Security Regulations, and the security screening order, gave CATSA an extremely clear, but restricted mandate in its passenger screening. CATSA screeners were responsible for and 
authorized to detect and to interdict prohibited items only, or to validate the identity of some non-passengers entering into secure air-side operations. In other words, CATSA could not use any profiling, risk-management, or policing methods in their security screening. CATSA argued that its ability to use these tools - such as behavioural profiling or risk management — would make the civil aviation security system much more secure. CATSA sought increased access to intelligence, a greater flexibility in screening-point staffing, and screening procedures. These moves were rejected by the expert panel and the Minister in the CATSA Act Review. ${ }^{11}$

In 'Our vision for aviation security', submitted to the Review, CATSA makes its case for an expanded mandate. CATSA can provide 'a national approach and consistency', 'public security', 'accountability', 'access to intelligence', and 'international networks' (CATSA 2006b: 5-6). The desire for national consistency among Canadian airports was one of the chief reasons for the creation of CATSA. The form of the organization balances accountability across a Board of Directors, the Minister for Transport, Infrastructure and Communities, and the Treasury Board (which approve, among other aspects, CATSA's budget and corporate plans). However, these other three priorities (public security, access to intelligence, and international networks) represent an expansion of its mandate.

Airports, in their submissions to the CATSA Act Review, argue that screening can be handled efficiently and effectively by their own private security staff - essentially a desecuritizing move (Aéroports de Montréal 2006; Canadian Airports Council 2006). They argue that security screening is not an existential threat and does not require additional powers or authorities. Aéroports de Montreal concludes: 'ADM strongly opposes any expansion of CATSA's mandate to encompass, for example, access control or policing functions, since this could be a further infringement of airports' control over their operations. Furthermore, the Minister should not be able to grant CATSA new responsibilities without consulting the airports' (2006: 3). The Canadian Airports Council writes: 'With the exception possibly of cargo security, airports are not in favour of an expanded mandate for CATSA, and airports should be consulted thoroughly before any expansion to CATSA's mandate takes place. Some airports have expressed an interest in taking over or sharing some of CATSA's functions at airports' (2006: 1). Against the argument that airports might be able to provide security screening, CATSA argues 'public security is the \#1 priority - CATSA's legislated mandate is air transport security - period. We are not in the business of operating parking, leasing space to businesses, airport cleaning and maintenance, or other areas of interest to airport authorities. Public security is compromised when screening operations are "cross-collateralized" with other airport operations' (5). Within this complex discursive environment, securitization/desecuritization is not 
simply a binary (on/off) condition but more processual. An examination of the submissions to the Advisory Panel illustrates who 'counts' as a stakeholder for the process, who counts as expert, whose voice is heard. While CATSA, the Advisory Panel, and the Review Secretariat clearly had primary speaking roles (with stakeholders in supporting roles) in this particular securitization drama, the important audience was the Minister.

This is a failed securitizing move: CATSA attempted to expand their mandate, to widen their security footprint, to convince the political elite that, due to the terror threat, more powers should accrue to the security service. CATSA publications emphasize the threat of terror, memorialize past attacks, and have instituted a training programme on terror for senior staff (David 2006). The attempt by CATSA to expand their mandate and securitize other areas of airport security was rejected by both the expert panel and the political elite. Both elite and experts were convinced of the threat, but none were convinced that special or expanded powers were needed. The Minister argued specifically that 'Responsibility for aviation security will continue to rest with the Minister of Transport, Infrastructure and Communities... CATSA's activities will be focused on its core aviation security-screening role: the effective and efficient screening of persons who access aircraft or restricted areas through screening points, the property in their possession or control, and the belongings or baggage that they give to an air carrier for transport' (Cannon 2007). Experts and elites argued that the public-private system, structured by rules from Transport Canada, could secure the system. In other words, the existential threat was accepted by the audiences, but not an expansion of powers. Consequently, the securitizing move was not accepted by the key audiences, the Advisory Panel and the Minister.

\section{Popular}

Within popular politics, the securitization of airport screening was easy to accomplish, particularly in countries that had 'focusing events' such as 9/11 (Birkland 1997, 2004). As Lyon observes, 'apart from short-term responses to some notorious hijackings over the past 30 years, airport security was never a topic that engaged the public imagination in Canada (or elsewhere for that matter)' (2006: 398). In 1985, the attack on Air India flight originated in Canada. Investigations determined that it was a result of weak baggage screening and the lack of reconciliation between passengers and luggage. However, passenger screening was not seen as such an important issue - the majority of hijacking or terror attacks occurred in the United States, particularly with reference to Cuba, or in Europe and the Middle East. ${ }^{12}$ In January 2003, the Standing Senate Committee on National Security and Defence tabled a report in Parliament titled The Myth of Security at Canada's 
Airports that called for a reinstatement of the RCMP presence and a wideranging overhaul of the system. Despite frequent interviews in the popular press by its author, this report did not resonate with the public, the policy, or the political audiences: it represents another failed securitizing move. ${ }^{13}$

However, the success of the securitization of aviation security can be seen in the popular reaction to two cases of investigative journalism. First, a journalist from the French-language paper Journal de Montréal infiltrated the secure, air-side areas at Trudeau airport in Montreal on a number of occasions through different access points. The journalist entered a catering company's facilities (Cara Foods) and gained access to restricted areas through a disused hanger. The reporter 'found a place to slip under the airport's perimeter fence, but there's no need to get your knees dirty: he also just walked in, repeatedly, as if he belonged. In prohibited zones he gained easy access to the outside of aircraft, to carts full of meals about to be loaded onto planes, and to a truck used to provide water to aircraft' (Gazette 2006). Though none of the checkpoints he passed were staffed by CATSA employees, or indeed the actual regulatory responsibility of CATSA, it was CATSA that was held publicly responsible. While CATSA has responsibility for key elements of aviation security, such as passenger and non-passenger screening at identified checkpoints, it is not responsible for overall perimeter security or security of air-side services. An editorial opined: 'Transport Minister Lawrence Cannon and CATSA chief Maurice Baril have got some explaining to do. Security can't be perfect, but it should surely be better than this'. Minister Cannon summoned Maurice Baril (who was CATSA's Chairman of the Board of Directors, who subsequently resigned) and CATSA President and CEO Jacques Duchesneau to Ottawa 'for further discussions' (Cannon 2006). In Canada, the responsibility for airport security, and the maintenance of air-side security, is shared among a number of different players in the airport and coordinated by Transport Canada through the Aviation Security Regulations. Thus, CATSA is responsible only for its six stated tasks, mandated in the CATSA Act. However, the popular response was that CATSA should be responsible for all of airport security - that all aspects of airport security were the responsibility of the government, because of the existential threat, because of the need for emergency powers. The (inappropriate) critique of CATSA - for, in essence, having a restricted mandate - is a clear demonstration that the public expected that CATSA would be responsible for all airport security (perhaps because of its much larger American counterpart the Transportation Security Administration or a 'misleading' corporate identity). For securitization theory, this implies that the audience, in this case the popular audience, may not simply accept securitization but also initiate an expansion of government powers. 
The second popular case that demonstrates how the wider public may not simply support, but widen securitization, is the 'revelation' by a Canadian television news programme that CATSA itself had security problems. CBC's investigative journalism programme, The Fifth Estate, broadcast 'Fasten Your Seatbelt' on 5 November 2005 (CBC 2005). A whistle-blower argued that 'customer service' was prioritized over security in passenger screening, and then a security expert, Steve Elson, demonstrated how to circumvent screening points (CBC 2006). The 'security expert' was described as being a former TSA inspector who currently consults on security matters (validating his expertise in both government and liberal economic terms). Once again, a complex web of regulations and responsibilities was simplified (and misconstrued). The whistleblower was a CATSA employee, and the programme highlighted the role of CATSA in passenger screening and the random nature of non-passenger screening. Within the programme, there was little discussion of the role of the actual regulator and ministry responsible for aviation security: Transport Canada. However, in an unaired portion of the interview with Senator Colin Kenny, one of the authors of The Myth of Security at Canada's Airports said, 'The problem is with Transport Canada. They set the regulations, CATSA simply follows them' (CBC n.d.). CATSA has specifically mentioned their attention to public pressure (Auditor-General 2006), and continuously measures passenger satisfaction rates.

Within the popular realm, journalists and government representatives had the roles as experts to 'speak authoritatively'. In these cases, CATSA representatives - who were experts on the legislated mandate of CATSA were unable to convince the populace through press releases, interviews, etc. that CATSA was not responsible for the security breeches. The socio-political context of Canada also determined 'what might be said'. In particular, the extremely complex interplay of authorities and responsibilities at the airport was radically simplified: CATSA was represented as being solely responsible for aviation security. Any failures of airport security, by themselves or their subcontractors, were laid at the feet of CATSA - as demonstrated by the Minister of Transport calling the President of CATSA back to Ottawa immediately after the Montreal incidents. The success of the securitization of aviation security within this realm is clear in the public criticism of CATSA for not using enough emergency measures to contain this existential threat. The travelling public, which is frequently surveyed by CATSA about its customer service, plays a large role in CATSA's internal discussions, but a smaller role in its discussions with external agencies.

These conclusions demonstrate why more nuance is needed in current models of securitization. More is going on than a simple politics of blame or bureaucratic infighting, although plainly some of those dynamics are in play. Rather, CATSA was being responsibilized for all of aviation security in 
Canada, despite its limited mandate. The popular pressure, I argue, is a representation of the 'facilitating conditions' in the popular imagination: the public was open to securitizing moves by the government. There is also the restriction of 'what might be said': in short, an over-simplification of complex regulatory systems and a misrepresentation of the level of attainable security. No system is completely secure - a fact that is often and easily acknowledged among experts in aviation security. But, this was not portrayed in the popular scene. Investigative journalists, in this case, had the position to speak authoritatively in a way that a Senator and other security experts did not. The public could only express their satisfaction with CATSA's screening as a customer service to CATSA, or in the popular media as a policing and counterterrorism agency. The failure of the expansion of the security mandate of CATSA in the elite realm and the simultaneous popular critique of CATSA's mandate indicate that the setting matters.

\section{Scientific}

In addition to a set of technical debates, CATSA is also engaged with the scientific community on how to effectively and efficiently screen passengers. I want to focus on the primary adoption of the risk management model, since this has been examined in the Auditor-General's Special Examination and CATSA Act Review process. CATSA was responsible for the purchase and implementation of a wide-scale technological upgrade to explosive detection systems, to meet Canadian and international standards. It has also won awards for its technological innovation for the RAIC programme that uses biometric identification. ${ }^{14}$ There is also a robust debate in expert circles regarding the use of private firms for security screening, whether airport security can be left to the private sector or should be provided by the government (Frederickson and Laporte 2002; Hainmüller and Lemnitzer 2003; Seidenstat 2004). ${ }^{15}$

CATSA is mandated to secure key elements of the civil aviation infrastructure through passenger screening. CATSA, however, provides screening according to the 'Security Screening Order', under the Aeronautics Act and the Canadian Aviation Security Regulations. As a crown corporation, CATSA is also bound by government policy to implement a 'risk management strategy', the key elements of which are the evaluation of potential impact and frequency of exposures to different risks. It then formulates a strategy that accepts, avoids, transfers, or mitigates that risk. Within this framework, 'It is government policy to identify, and reduce or eliminate risks to its property, interests and employees, to minimize and contain the costs and consequences in the event of harmful or damaging incidents arising from those risks, and to provide for adequate and timely compensation, restoration and recovery' 
(Canada. Treasury Board of Canada 2001). CATSA actively engaged the academic and expert communities in formulating its risk management strategy (Brodeur 2006) ${ }^{16}$ and its proposed Security Management Systems approach (Salter 2007). The CATSA executive asked for training in risk management and, in 2005, the International Centre for Comparative Criminology organized two seminars (in Paris and in Montréal) on risk management. The academic experts at these workshops represented the fields of surveillance studies, criminology, sociology, public health, environmental studies, and risk management itself.

The core issues for the experts were the following: "uncertainty theoretically supersedes risk and rule-based and risk-based models are not mutually exclusive in the promotion of security. Not only can they be reconciled in practice, but they must' (Brodeur 2006: 324). This poses two problems for CATSA, which later became evident in the CATSA Act Review and the Auditor-General's Special Examination: uncertainty within the public security fields makes measurement impossible; following security regulations alone would be insufficient to demonstrate risk management.

Among the social scientists represented at the Montréal seminar, there was a consensus that the tactic of risk management, used often in environmental planning and other scientific realms, cannot be easily transferred to the social realm (Zedner 2006: 424). Ericson, an internationally renowned criminologist who pioneered the critical study of risk management, argued, 'risk management systems can restrict freedom, invade privacy, discriminate, and exclude populations. Such self-defeating costs and the uncertainties they entail can be minimized only by infusing risk management systems with value questions about human rights, well-being, prosperity, and solidarity' (2006: 346). These experts questioned not only the empirical reliability of risk management (Manning 2006: 457), but also the ideological function of screening by risk (O'Malley 2006: 420). These experts agreed that the move to a risk-based model of airport screening would require more specific intelligence and the widening of CATSA's mandate. But, they also stressed that because of the radical incalculability of the threat of terror, risk-based security screening had to be combined with rules-based screening. Since risk management could not prevent terror, and may cause potential problems, the problem of airport security had to be made explicitly political. Within these seminars, the setting was academic: experts were selected because of their scholarly credentials and the discourse was in an academic mode. ${ }^{17}$

At root, the experts attempted a desecuritizing move: since uncertainty trumps risk, the lack of metrics makes measurement (and thus management of risk) impossible. Thus, the security screening process must be political. Since a risk-based approach cannot guarantee security, and the risk- and rule-based systems were in some conflict, CATSA (and by implication Transport Canada, 
the regulator) must deal with these uncertainties and risks, sensitive to the politics of the situation. Screening procedures could not be an emergency, existential threat that required extraordinary powers or policies. Because security was unobtainable, the process had to remain steadfastly political. Though there was a consensus among the scientific field, this desecuritizing move failed - none of the other audiences were convinced, as demonstrated below in the review of the technocratic setting.

\section{Technocratic}

While the CATSA Act Review had the political elite as its audience, the Auditor-General's Special Examination had only the Office of the AuditorGeneral as its audience. It was also presented to the CATSA Board of Directors, with clear implications for the Minister - but the authors of the report were a team of auditors not politicians. A Special Examination of CATSA was undertaken by the Auditor-General of Canada during November 2005-June 2006 (a similar time period to the CATSA Act Review process). The Auditor-General appraised the extent to which CATSA was fulfilling and measuring its mandate, as well as other financial and management standards. ${ }^{18}$ It is beyond the mandate of the Auditor-General's Special Examination to analyse the mandate of the organization (Canada. Office of the Auditor General 2006: 9). CATSA tried to use the Special Examination as another venue to expand its mandate, which, as I argue above, is a securitizing move accruing more governmental power to manage an existential threat. Just as CATSA attempted this with respect to the elite audience of the CATSA Act Review, they also attempted this in the technocratic setting. As the report concludes: 'CATSA does not wish to be constrained by its limited mandate. CATSA would like to have more control over the way screening operations are conducted, the allocation of screening staff, and the selection of screening equipment; and it would like direct access to intelligence information' (3). The case for the expansion of CATSA's mandate is made in terms of security, emergency, and extraordinary powers: it satisfies the internal criteria for a securitizing move. Here is the key moment: 'CATSA's view is that counterterrorism is a key aspect of its work. This is evident in CATSA documents. Transport Canada has stated that CATSA's current mandated responsibilities do not specifically include counter-terrorism' (14). The CATSA Act Review Advisory Panel also notes this troubled relationship: 'there appears to be a high level of frustration and mistrust between Transport Canada and CATSA at the national level' (CATSA Act Review 2006: 137).

The Auditor-General's report is relatively neutral in this bureaucratic infighting but that neutrality stands as a rejection of the securitizing move. In short, the securitizing move fails because it does not accept 'security' as a 
legitimate justification for reevaluating the mandate of CATSA: 'This Special Examination did not question CATSA's mandate; rather it assessed CATSA's systems and practices within its mandate and the regulations that govern the aviation security system' (9). Despite the best efforts of CATSA to make the mandate part of the audit, in order to use the report as a tool in their securitizing move, the Auditor-General did not accept the move.

Within the Auditor-General's review, who may speak and what may be said is radically different. CATSA officials prepared reports for the AuditorGeneral's team who also consulted with an expert team. ${ }^{19}$ The terms of reference for the report, however, were specific to the crown corporation model and its relevant legislation regarding financial administration. Essentially, security was not the object of study: however, risk management was under scrutiny. Thus, while similar messages were made by CATSA and Transport Canada, they were expressed in different, more managerial language. The audience for this report was primarily the Board of Directors, and indirectly the responsible Minister, Treasury Board Secretariat, and the Parliament of Canada to which the Auditor-General reports. However, the review results were also marshalled in the CATSA Act Review process, in order to bolster the case for a refusal of the securitizing move to increase CATSA's mandate. Thus, the same securitizing/desecuritizing moves are played out, but in a totally different register within different sectors.

\section{Settings for Canadian Aviation Security}

This dramaturgical analysis of CATSA during the crucial 2005-2006 period has demonstrated the need for an analytical disaggregation of the actoraudience model in securitization theory. Within different settings (popular, elite, scientific, and technocratic), different actors were empowered to speak, and different audiences constituted - the rules of those discursive relationships were also impacted by setting. Stakeholders from the CATSA Act Review had no voice in the experts' academic workshop; reports on the measurement of security for the Advisory Panel were not used in the Auditor-General's Special Examination. These different settings also defined the content of securitizing moves: though there was a common desire to expand CATSA's security mandate, it was done with different arguments in the expert workshop, the Special Examination, and the CATSA Act Review. Finally, the CATSA case demonstrates the need to parse the success/failure of securitizing moves in a more nuanced way. CATSA's securitizing move was premised on the acceptance of an existential threat (which is commonly believed), the description of a crisis or emergency (accepted by some and rejected by others), and the accrual of new executive power (which was completely rejected). 


\section{Conclusion}

The CS model of securitization is provocative and productive of many political and research agendas. Making the model more sensitive to who may speak, who can hear, and what can be said within particular settings allows us to evaluate the politics of successful moves to securitize or desecuritize an issue. This kind of analysis necessarily involves an examination of a particular setting over time, a factor often downplayed in CS analysis. Sector studies in public safety, security studies, migration, trafficking, minority rights, and disease can all benefit from a clearer consideration of audience-speaker co-constitution of authority and knowledge, the weight of social context, and the degree of success of particular moves.

Desecuritization is seen a priori as more politically preferable than securitization (Wæver 1999: 335). Deliberative politics are by definition more democratic than exceptional politics. This has led to the important debate led by Aradau (2001, 2004, 2006), Alker (2006), Taureck (2006), Behnke (2006), Huysmans (2006), and Floyd (2007) on the ethical relationship of emancipation and politicization to securitization. This follows from a productive discussion on the role of security experts (Eriksson 1999; Goldmann 1999; Wæver 1999; Williams 1999). While this article does not engage this debate extensively, we would argue that, tactically, analysts and experts must understand the political dynamics of successful securitization and desecuritization processes if they wish to intervene. In this, I once again take the lead from Foucault who says that his own analysis has sprung from his personal experiences and a kind of a malaise with objective, abstract, Archimedian theory. In building from his insider knowledge of and outsider status within institutions (such as the clinic, human sexuality, or the penal system), Foucault conducts a 'history of the present' - to ask not 'what does the prison mean' but 'how does the prison mean?' With particular experience in different realms of security studies, it seems that securitization theory might contribute to this kind of history of the present. This is to say that the process of successful securitization and desecuritization operates differently within different settings. If, as security experts, it is part of our role to intervene in the securitization/ desecuritization process, then we must gain a tactical knowledge of the conditions for success and failure. There is an assumption in this debate about securitization/desecuritization that experts are significant or important voices. It is true that 'in writing or speaking security, the analyst him/herself executes a speech act, this speech act is successful if the problem raised becomes recognized as a security problem in the academy and/or in the wider policy making discourse' (Floyd 2007: 336). But, this is where I differ with Floyd's consequentialist view of securitization: the issue is not only the results of successful (de)securitization, but to understand the conditions of success. If the 
security analyst is to 'encourage some securitizations and renounce others', that analyst needs to understand not only the consequences of securitization, but the consequences of their intervention (2007: 339). To engage with the ethical or normative dilemma of the analyst's involvement in the securitization process, we must first ask 'what makes an intervention successful'? Tactically, it is important to understand also how (de)securitizing moves fail — and this has not received enough attention within the literature.

A research programme into new areas of securitization theory is prompted by this excursion into dramaturgical analysis. What is the appropriate level of analysis of settings: national, bureaucratic, organizational, cultural, linguistic? To what extent do comparative studies of securitizing moves indicate necessary and sufficient conditions for success or failure? In particular, I have made the (warranted) assumption that the public imaginary suffers a kind of issueentropy. To make a threat present requires a continual investment and spending of political capital. This argument has been made about political identity and danger in foreign policy by Campbell (1993). De Goede (2008), Muller (2008b), and other critical scholars have made similar arguments about professional and international constructions of risk and threat. However, more research must be conducted on how the successful construction of security threats or risks feeds into processes of securitization. The field of securitization studies is fertile, and much more work must be done precisely on the role of politics in these processes.

\section{Acknowledgements}

I acknowledge the support of the Social Sciences and Humanities Research Council of Canada for this project. I also thank my colleague Patrick T. Jackson, who provided early and productive commentary on this paper, when it was presented in a roundtable organized by David Grondin and Alex Macleod at the ISA-Northeast conference. Two reviewers at the JIRD were also very generous with their time and comments.

\section{Notes}

1 This is not to discount the importance of Huysmans (2006) or Taureck (2006). However, these authors do not focus on the social aspect of securitization. Huysmans demonstrates how the process of securitization is linked to bureaucratic techniques of governance and the concept of the political, while Taurek examines how the realist and post-structural aspects of Waever coexist.

2 Because of his provocative work in understanding identity, space, and social situations as constructed, Goffman is undergoing a revival in some sociological circles. See Borreca (1993), Lemert and Branaman (1997), Brown (2005), and Hajer (2005).

3 These dynamics have been explored in international relations, particularly in the domain of foreign policy analysis, strategic studies (strategic culture), public administration, and organizational anthropology. 
4 See Anonymous (2004).

5 Merelman (1969) discusses the importance of 'settings' as a key concept but does not make a general claim as to how they might be studied.

6 See also Salter $(2006,2007)$.

7 By scientific, in this case, I mean academics and experts who focus on air transportation security, airport management, or regulation.

8 The same argument can be made about the Transportation Security Administration in the United States.

9 Other responsibilities not germane to this paper include Airport policing contributions program, Canadian Air Carrier Protective Program, and Restricted Area Identification Card (RAIC) for major airports.

10 This was required in Section 33 of the Canadian Air Transport Security Authority Act. The three experts included a political scientist, a professor of public administration, and a former airport administrator.

11 It should be noted that the grounds for rejection may be different. The Auditor-General's Special Examination notes 'on-going issues between CATSA and Transport Canada', in particular this debate regarding mandate and scope of operations (Canada. Office of the Auditor General 2006: 15).

12 To demonstrate the importance of popular consent or facilitating conditions, take an event that did not change the popular view of aviation screening: the Millennium Bomber, Ahmed Ressam. An Al-Qaeda splinter cell, Ressam used a fake passport to travel to Afghanistan for training in explosives, flew to Vancouver, rented a van and assembled a truck bomb with the intention of driving it to Los Angeles International Airport for detonation on the Millennium, January 12000. He was caught by an observant US Customs Guard at Port Angeles, in Washington State. This terrorist flew from Montreal, through Frankfurt, to Karachi. And back. And then flew to Vancouver, where he assembled his truck bomb. He was not identified or caught. Because the attacks of $9 / 11$ had not yet firmly implanted the idea of hijacked planes themselves as weapons of mass destruction, the ability of Ressam to fly internationally and domestically was not seen as a failure of the aviation security system, but rather a failure of the policing system.

13 While the Senate committee report is referenced by journalists, it has not gained much currency among bureaucratic audiences and is not a touchstone for policy discussions.

14 There is an interesting story about technical standards and the successful securitization of biometrics (Amoore and de Goede 2005; Amoore 2006; Muller 2008a), which is outside the scope of this article.

15 There is no scientific consensus among experts regarding the balance between the efficiency of private sector screening and the (presumed) efficacy of government screening, which is a direct result of the lack of reliable data about the success of screening. One could make the argument that, among the scientific community, there is a contested process of securitization. Quotidian aviation security is not an existential threat, except on those occasions when it is.

16 The proceedings of these two seminars were published in the Canadian Journal of Criminology and Criminal Justice, 48 (3) edited by Jean-Paul Brodeur.

17 At a later meeting on the viability of the Security Management Systems approach for CATSA, different experts were marshalled: industry and standards organizations were heavily favoured, and academic participation was limited.

18 The complete Special Examination is classified as secret, and so this analysis is based on the redacted report, available through the CATSA website.

19 Including the author, a counter-terrorism and intelligence expert, and an expert in public administration. 


\section{References}

Abdolian, Lisa Finnegan and Harold Takooshian (2003) 'The USA PATRIOT Act: Civil Liberties, the Media, and Public Opinion', Fordham Urban Law Journal 30(4): 1438.

Aéroports de Montréal (2006) 'ADM's position on the five-year CATSA review', Position paper submitted to CATSA Act Review. Available at: http://www.tc.gc.ca/tcss/CATSA/SubmissionsSoumissions/CATSA_new.doc (6 July).

Alker, Hayward (2006) 'On Securitization Politics as Contexted Texts and Talk', Journal of International Relations and Development 9(1): 70-80.

Amoore, Louise (2006) 'Biometric Borders: Governing Mobilities in the War on Terror', Political Geography 25(3): 336-51.

Amoore, Louise and Marieke de Goede (2005) 'Governance, Risk and Dataveillance in the War on Terror', Journal Crime, Law and Social Change 43(2-3): 149-73.

Anonymous (2004) 'Faculty Bingo', International Studies Perspectives 5(1): 119.

Aradau, Claudia (2001) 'Beyond Good and Evil: Ethics and Securitization/Desecuritization Techniques', Rubikon: International Forum of Electronic Publications.

Aradau, Claudia (2004) 'Security and the Democratic Scene: Desecuritization and Emancipation', Journal of International Relations and Development 7(4): 388-413.

Aradau, Claudia (2006) 'Limits of Security, Limits of Politics? A Response', Journal of International Relations and Development 9(1): 81-9.

Aradau, Claudia and Rens van Munster (2007) 'Governing Terrorism Through Risk: Taking Precautions, (Un)Knowing the Future', European Journal of International Relations 13(1): $89-115$.

Aradau, Claudia, Luis Lobo-Guerrero and Rens van Munster, eds (2008) 'Security, Technologies of Risk, and the Political', Security Dialogue 39(2-3): 147-54.

Balzacq, Thierry (2005) 'The Three Faces of Securitization: Political Agency, Audience, and Context', European Journal of International Relations 11(2): 171-201.

Balzacq, Thierry (2008) 'The Policy Tools of Securitization: Information Exchange, EU Foreign and Interior Policies', Journal of Common Market Studies 46(1): 75-100.

Behnke, Andreas (2006) 'No Way Out: Desecuritization, Emancipation and the Eternal Return of the Political - a Reply to Aradau', Journal of International Relations and Development 9(1): $62-9$.

Bigo, Didier (2006) 'Globalized (in)Security: The Field and the Ban-opticon', in Didier Bigo and Anna Tsoukala, eds, Terror, Insecurity, Liberty: Illiberal Practices of Liberal Regimes after 9-11, 5-49, London: Routledge.

Birkland, Thomas A. (1997) After Disaster: Agenda Setting, Public Policy, and Focusing Events, Washington, DC: Georgetown University Press.

Birkland, Thomas A. (2004) 'Learning and Policy Improvement after Disaster: The Case of Aviation Security', American Behavioral Scientist 48(3): 341-64.

Borreca, Art. (1993) 'Political Dramaturgy: A Dramaturg's (Re)View', The Drama Review 37(2): 56-79.

Brodeur, Jean-Paul (2006) 'Introduction', Canadian Journal of Criminology and Criminal Justice 48(3): 323-44.

Brown, Robert E. (2005) 'Acting Presidential: The Dramaturgy of Bush Versus Kerry', American Behavioral Scientist 49(1): 78-91.

Butler, Judith (1990) Gender Trouble: Feminism and the Subversion of Identity, New York: Routledge.

Buzan, Barry (1991) People, States, and Fear: An Agenda for International Security Studies in the Post-Cold War Era, 2nd edn, Boulder: Lynne Rienner. 
Buzan, Barry and Ole Wæver (1997) 'Slippery? Contradictory? Sociologically Untenable? The Copenhagen School Replies', Review of International Studies 23(2): 241-50.

Buzan, Barry, Ole Wæver and Jaap de Wilde (1998) Security: A New Framework for Analysis, Boulder: Lynne Rienner.

Campbell, David (1993) Writing Security: United States Foreign Policy and the Politics of Identity, Revised edition. Minneapolis: University of Minnesota Press.

Canada. Office of the Auditor General (2006) 'Canadian Air Transport Security Authority: Special Examination Report', Redacted Version, Ottawa.

Canada. Treasury Board of Canada (2001) Risk Management Policy, Ottawa, Available at: http:// www.tbs-sct.gc.ca/pubs_pol/dcgpubs/RiskManagement/riskmanagpol_e.asp (3 July, 2008).

Canadian Air Transport Security Authority (2006a) 'AGILE: Prevention, preparedness and proficiency in counter-terrorism', SL-812/11-06. Position paper presented the Canadian Air Transport Security Authority Act Review, Ottawa.

Canadian Air Transport Security Authority (2006b) 'Our Vision for Aviation Security', SL-811/ e-06. Position paper presented the Canadian Air Transport Security Authority Act Review, Ottawa.

Canadian Air Transport Security Authority Act Review (2006) Flight Plan: Managing the Risks in Aviation Security: Report of the Advisory Panel, Ottawa: CATSA Act Review Secretariat.

Canadian Airports Council (2006) 'CATSA Act 5-Year Review CAC Position Paper', Position paper presented the Canadian Air Transport Security Authority Act Review. Ottawa. Available at: http://www.tc.gc.ca/tcss/CATSA/Submissions-Soumissions/CAC.pdf (6 July).

Cannon, Lawrence (2006) 'Minister Cannon Issues Statement on Security at Montréal Pierre Elliott Trudeau International Airport', Transport Canada News Release. No. H117/06. 27 September, Ottawa.

Cannon, Lawrence (2007) 'Minister Cannon Announces Outcome of the Canadian Air Transport Security Authority Act Review', Transport Canada News Release. No. H 162/07. 4 September, Ottawa.

CBC. The Fifth Estate (2005) Fasten Your Seatbelt, originally aired 5 November.

CBC. The Fifth Estate (2006) Fasten Your Seatbelt Update, originally aired 22 November.

CBC. The Fifth Estate (2008) 'Colin Kenny Interview', Fasten Your Seatbelt, Available at: http:// www.cbc.ca/fifth/fastenseatbelts/kenny_interview.html, 4 January.

David, Charles-Philippe, ed. (2006) Terrorism: Risks, Trends, Responses, Montréal: Chaire Raoul-Dandurand and Canadian Air Transport Security Authority.

De Goede, Marieke (2008) 'Beyond Risk: Premediation and the Post-9/11 Security Imagination', Security Dialogue 39(2-3): 155-76.

Doty, Roxanne Lynn (2007) 'States of Exception on the Mexico-U.S. Border: Security, "Decisions," and Civilian Border Patrols', International Political Sociology 1(2): 113-37.

Eriksson, Johan (1999) 'Observers or Advocates? On the Political Role of Security Analysts', Cooperation and Conflict 34(3): 311-30.

Floyd, Rita (2007) 'Towards a Consequentialist Evaluation of Security: Bringing Together the Copenhagen and Welsh Schools of Security Studies', Review of International Studies 33(2): 327-50.

Foucault, Michel (1980) 'Truth and Power', in Colin Gordon, ed., Power/Knowledge: Selected Interviews and other Writings 1972-1977, 109-33, New York: Pantheon Books.

Frederickson, H. George and Todd R. Laporte (2002) 'Airport Security, High Reliability and the Problem of Rationality', Public Administration Review 62(s1): 33-43.

Gazette, Montreal (2006) 'There is No Excuse for Lax Airport Security', (Final Edition). 12 September: A18.

Goffman, Erving (1959) The Presentation of the Self in Everyday Life, New York: Doubleday.

Goffman, Erving (1974) Frame Analysis: An Essay on the Organization of Experience, Boston: Northeastern University Press. 
Goldmann, Kjell (1999) 'Issues, Not Labels, Please!: Reply to Eriksson', Cooperation and Conflict 34(3): 331-3.

Hainmüller, Jens. and Jan Martin Lemnitzer (2003) 'Why do Europeans Fly Safer? The Politics of Airport Security in Europe and the US', Terrorism and Political Violence 15(4): 1-36.

Hajer, Maarten A. (2005) 'Setting the Stage: A Dramaturgy of Policy Deliberation', Administration \& Society 36(6): 624-47.

Hansen, Lene (2000) 'The Little Mermaid's Silent Security Dilemma and the Absence of Gender in the Copenhagen School', Millennium 29(2): 285-306.

Huysmans, Jef (1995) 'Migrants as a Security Problem: Dangers of "Securitizing" Societal Issues', in Robert Miles and Eitrich Thranhardt, eds, Migration and European Integration: The Dynamics of Inclusion and Exclusion, 53-72, London: Pinter.

Huysmans, Jef (2006) The Politics of Insecurity: Fear, Migration and Asylum in the EU, London: Routledge.

Jackson, Patrick T. and Daniel H. Nexon (1999) 'Relations before States: Substance, Process, and The Study of World Politics', European Journal of International Relations 5(3): 291-332.

Krebs, Ronald R. and Patrick T. Jackson (2007) 'Twisting Tongues and Twisting Arms: The Power of Political Rhetoric', European Journal of International Relations 13(1): 35-66.

Lemert, Charles and Ann Branaman, eds (1997) The Goffman Reader, Oxford: Blackwell.

Lyon, David (2006) 'Airport Screening, Surveillance, and Social Sorting: Canadian Responses to the 9/11 Context', Canadian Journal of Criminology and Criminal Justice 48(3): 397-411.

Manning, Peter K. (2006) 'Reflections on Risk Analysis, Screening, and Contested Rationalities', Canadian Journal of Criminology and Criminal Justice 48(3): 453-69.

McSweeney, Bill (1996) 'Identity and Security: Buzan and the Copenhagen School', Review of International Studies 22(1): 81-93.

McSweeney, Bill (1998) 'Durkheim and the Copenhagen School: A response to Buzan and Wæver', Review of International Studies 24(1): 137-40.

Merelman, Richard M. (1969) 'The Dramaturgy of Politics', Sociological Quarterly 10(2): 216-41.

Monahan, Torin (2006) 'Securing the Homeland: Torture, Preparedness, and the Right to Let Die', Social Justice 33(1): 95-105.

Muller, Benjamin J. (2008a) 'Travellers, Borders, Dangers: Locating the Political at the Biometric Border', in Mark B. Salter, ed., Politics at the Airport, 127-44, Minneapolis: University of Minnesota Press.

Muller, Benjamin J. (2008b) 'Securing the Political Imagination: Popular Culture the Security Dispositif and the Biometric State', Security Dialogue 39(2-3): 199-220.

O'Malley, Pat (2006) 'Risk, Ethics, and Airport Security', Canadian Journal of Criminology and Criminal Justice 48(3): 413-21.

Salter, Mark B. (2006) 'Governmentalities of an Airport: Heterotopia and Confession', International Political Sociology 1(1): 49-67.

Salter, Mark B. (2007) 'SeMS and Sensibility: Security Management Systems and the Management of Risk in the Canadian Air Transport Security Authority', Journal of Air Transportation Management 13(6): 389-98.

Seidenstat, Paul (2004) 'Terrorism, Airport Security, and the Private Sector', Public Administration Review 21(3): 275-91.

Stritzel, Holger (2007) 'Towards a Theory of Securitization: Copenhagen and Beyond', European Journal of International Relations 13(3): 357-83.

Sylvester, Christine (2003a) 'Dramaturgies of Violence', borderlands e-journal 2(2): Available at: http://www.borderlands.net.au/vol2no2_2003/sylvester_editorial.htm (last accessed 15 August, 2008). 
Sylvester, Christine (2003b) 'Global "Development” Dramaturgies/Gender Stagings', borderlands e-journal 2(2): Available at: http://www.borderlands.net.au/vol2no2_2003/sylvester_global.htm (last accessed 15 August, 2008).

Taureck, Rita (2006) 'Securitization Theory and Securitization Studies', Journal of International Relations and Development 9(1): 53-61.

Wæver, Ole (1995) 'Securitization and Desecuritization', in Ronnie D. Lipschutz, ed., On Security, 46-86, New York: Columbia University Press.

Wæver, Ole (1999) 'Securitizing Sectors? Reply to Eriksson', Cooperation and Conflict 34(3): $334-40$.

Williams, Michael C. (1999) 'The Practices of Security: Critical Contributions: Reply to Eriksson', Cooperation and Conflict 34(3): 341-4.

Williams, Michael C. (2003) 'Words, Images, Enemies: Securitization and International Politics', International Studies Quarterly 47(4): 511-31.

Zedner, Lucia (2006) 'Neither Safe Nor Sound? The Perils of Possibilities of Risk?' Canadian Journal of Criminology and Criminal Justice 48(3): 423-34.

\section{About the Author}

Mark B. Salter is an Associate Professor at the School of Political Studies, University of Ottawa. He is currently researching the questions of risk, security, and mobility by focusing on the sites of the airport and the border. He is editor of Politics at the Airport (University of Minnesota) and with Elia Zureik of Global Policing and Surveillance: Borders, Security Identity (Willan). $\mathrm{He}$ is the sole author of Rights of Passage: the Passport in International Relations (Lynne Rienner) and Barbarians and Civilization in International Relations (Pluto, also published in Chinese, Xinhua) and articles in Geopolitics, Citizenship Studies, International Political Sociology, Alternatives, Security Dialogue, International Studies Perspectives, Journal of Air Transport Management, and Journal of Transportation Security. In autumn 2008, he was visiting fellow at the Centre for Research in the Arts, Social Sciences, and Humanities and visiting scholar at the Centre of International Studies at the University of Cambridge. 